\title{
Influence of Plant Growth Promoting Substances on Rooting of Bush Pepper Cuttings
}

\author{
H.S. Sannidhi ${ }^{1 *}$, H.R. Bhoomika ${ }^{1}$, B.M. Priyanka ${ }^{1}$, M.S. Nandish ${ }^{2}$, \\ G. Raviraja Shetty ${ }^{1}$ and M. Ganapathi ${ }^{3}$ \\ ${ }^{1}$ Department of Plantation, Spice, Medicinal and Aromatic Crops, ${ }^{3}$ Department of crop \\ Physiology, College of Horticulture, Mudigere, Chickmagalur District, 577132, India \\ ${ }^{2}$ Department of microbiology, College of Agriculture, Shivamogga, India \\ *Corresponding author
}

\section{A B S T R A C T}

\begin{tabular}{|l|}
\hline K e y w o r d s \\
$\begin{array}{l}\text { Black pepper, Bush } \\
\text { pepper, Plagiotropic, } \\
\text { Hormones, Root, Cuttings }\end{array}$ \\
\hline Article Info \\
\hline $\begin{array}{l}\text { Accepted: } \\
12 \text { August } 2018 \\
\text { Available Online: } \\
\text { 10 September } 2018\end{array}$ \\
\hline
\end{tabular}

Bush pepper is a miniature black pepper (Piper nigrum L.) plant grown in the form of a bush as potted plant with decorative and economic value, raised from lateral branches (plagiotrops) of yielding vines. Growth hormones and plant growth promoting rhizomicroorganisms were evaluated for their effects on rooting of plagiotropic cuttings of black pepper. The fruiting branches of black pepper variety Panniyur 1 were employed for the study. There were totally nineteen treatments that included PGPRs viz. Azospirillum lipoferum and Pseudomonas fleuroscens and plant growth hormones viz. IBA, NAA and 2, $4 \mathrm{D}$ at different concentrations. The treatment $\mathrm{T}_{8}$ (IBA $1000 \mathrm{ppm}$ ) proved to be the best for rooting by recording maximum values for percentage rooting (65.30), fresh weight (1.10 $\mathrm{g}$ ), dry weight of root $(0.53 \mathrm{~g})$, per cent survival (54.04) followed by IBA $1250 \mathrm{ppm}$. The treatment also recorded maximum net income (Rs. 11492.00 / 1000 cuttings) and highest benefit cost ratio (1: 3.43$)$.

\section{Introduction}

Black pepper (Piper nigrum L.) is a perennial woody vine native of Indian subcontinent. It has gained global recognition as the "king of spices" and "black gold" (Devasahayam et al., 2010) due to its economical importance. Pepper berries are valued both as food flavourants and the medicine worldwide.

The vine can be propagated both by sexual as well as asexual means. The commercial method of propagation is through cuttings. The vine produces four types of shoots namely, orthotropic shoots, runner shoots, plagiotropic shoots and geotropic shoots. In India runner shoots are extremely employed for propagation. Two to three nodal cuttings are prepared out of the runner shoots and the rooted cuttings are usually trained on trees / standards to enable the plant to climb upwards and grow out into a vine. But when the laterals are used as planting material, the resultant plants grow like a bush. 
Bush pepper is a miniature pepper plant in the form of a bush usually grown as a potted plant with decorative and economic value. The plant starts flowering during the same year of planting and goes on producing spikes from all its branches yielding berries throughout the year whereas, in vines they take three to four years. Though bush pepper is not comparable with vine pepper in terms of economic returns, it can be grown in the region where land is a limiting factor such as in apartments as a component in terrace garden, in nontraditional areas where black pepper is not cultivated and as an intercrop in coconut and arecanut orchards or any perennial orchards. It is also ideal in conservation and maintenance of black pepper germplasm in a limited area. Compared to runner shoots, the rooting percentage of laterals was found to be far less, that is less than 30 per cent (Sujatha et al., 2009) which is a limiting factor in production of bush pepper. Hence the experiment was conducted to study the effect of growth promoting substances on rooting of lateral cuttings of black pepper.

\section{Materials and Methods}

The experiment was conducted in a naturally ventilated polyhouse at College of Horticulture, Mudigere. The healthy one-yearold plageotropic shoots of Panniyur-1 variety were collected and the three nodal cuttings of $10-15 \mathrm{~cm}$ long were prepared by giving a slant cut at the bottom. The cuttings were planted in polybags of $15 \mathrm{~cm} \times 10 \mathrm{~cm}$ size filled with soil, sand and FYM in the ratio of 2:1:1.

The experiment was laid out in a completely randomized design with nineteen treatments including control. Growth hormones and plant growth promoting rhizo microorganism formulations were used at different concentrations. Each treatment was replicated thrice. The treatment details are as follows, $\mathrm{T}_{1}$-Control, $\mathrm{T}_{2}$-Pseudomonas fluorescens @
$5 \mathrm{ml} /$ polybag, $\mathrm{T}_{3}$-Pseudomonas fluorescens @ 10ml / polybag, $\mathrm{T}_{4}$-Azospirillum lipoferum@5ml / polybag, $\mathrm{T}_{5}$-Azospirillum lipoferum@10ml / polybag, $\mathrm{T}_{6}$-Keradix powder, T 7 -IBA 1000 ppm, T8-IBA 750 ppm, T9-IBA $1250 \mathrm{ppm}, \mathrm{T}_{10}$-NAA $200 \mathrm{ppm}, \mathrm{T}_{11^{-}}$ NAA 400 ppm, T 12 -NAA 600 ppm, T $13-2$, 4 D 100 ppm, $\mathrm{T}_{14}-2$, 4 D 200 ppm, $\mathrm{T}_{15}-2$, 4 D 300 ppm, $\mathrm{T}_{16}$-Cow dung slurry at dilution with water@1:1, $\mathrm{T}_{17}$-Cow dung slurry at dilution with water @ 1:2, $\mathrm{T}_{18}$-Tender coconut water @ 50 per cent dilution with water, $\mathrm{T}_{19}$-Tender coconut water concentrated.

The basal end of the cuttings were dipped in different concentrations of IBA $(750 \mathrm{ppm}$, 1000 ppm, 1250 ppm), NAA (200 ppm, 400 ppm, 600 ppm) 2,4-D (100 ppm, 200 ppm, $300 \mathrm{ppm}$ ) for 40-50 seconds and air dried. Liquid cultures of Pseudomonas and Azospirillum were applied to potting media at two different levels i.e., 5ml/polybag and 10 $\mathrm{ml} /$ polybag. For keradix treatment, the basal end of the cuttings $(2.5-3 \mathrm{~cm})$ were dipped in water and later dipped in keradix powder taken in a beaker. The cuttings were tapped to the brim of the container to remove the excess powder. The cuttings were dipped in cow dung slurry and tender coconut water at different dilution levels for 10 minutes and planted in polybags containing rooting media up to a depth of one node.

The data pertaining to various root parameters were tabulated and statistically analyzed using Completely Randomized Design. The inference was drawn after comparing the calculated $F$ values with the table $F$ values at $5 \%(\mathrm{P}=0.05)$ level of significance.

\section{Results and Discussion}

The rooting percentage was significantly influenced by the different treatments (Table 1) and the treatment $T_{8}($ IBA $-1000 \mathrm{ppm})$ recorded maximum rooting $(65.30 \%)$, which 
was on par with IBA $1250 \mathrm{ppm}(63.52 \%)$, IBA $750 \mathrm{ppm}(61.20 \%)$ and Azospirillum lipoferum $10 \mathrm{ml}(61.84 \%)$. Whereas, control recorded the minimum percentage of rooting (38.90).This might be due to the action of auxin in causing the hydrolysis and translocation of carbohydrates and nitrogenous substances at the base of cuttings, helped in better root initiation. The present results are in harmony with the findings of Polat and Caliskan (2009) in pomegranate stem cuttings, Bandi et al., (2012) in guggal stem cuttings and Susaj et al., (2012) in rose cutttings.

The treatment $\mathrm{T}_{8}$ (IBA $1000 \mathrm{ppm}$ ) also recorded maximum fresh weight $(1.10 \mathrm{~g})$ and dry weight $(0.53 \mathrm{~g})$ of root,which was on par with IBA $1250 \mathrm{ppm}$ (1.00 $\mathrm{g}$ of fresh weight and $0.50 \mathrm{~g}$ of dry weight respectively). While the minimum fresh weight $(0.59 \mathrm{~g})$ and dry weight $(0.14 \mathrm{~g})$ of roots was recorded in untreated control.This might be due to better mobilization of primary metabolites through increased root number resulting in higher accumulation of fresh and dry matter. The results are in agreement with the findings of Kaur et al., (2002) in grapevine, Murthy et al., (2010) in vanilla cuttings and Bhagya and Sreeramu (2013) in Vitex nigundo.

The maximum survival percentage of rooted cuttings was recorded in IBA $1000 \mathrm{ppm}$ (54.04), as depicted in Figure 1 which was on par with IBA $1250 \mathrm{ppm}$ (52.20). While minimum survival percentage of rooted cuttings $(30.56 \%)$ was recorded in control. The cuttings treated with IBA resulted in development of effective root system and increase in number and length of roots per cutting which might have influenced the uptake of nutrients and water. The overall performance in relation to growth parameters of root and shoots were comparatively better in this treatment which ultimately increased the survival percentage. The results are in conformity with Das et al., (2006) in olive and Camellia et al., (2009) in Jatropha curcus.

Fig.1 Effect of growth hormones and PGPRs on per cent survival of rooted cuttings

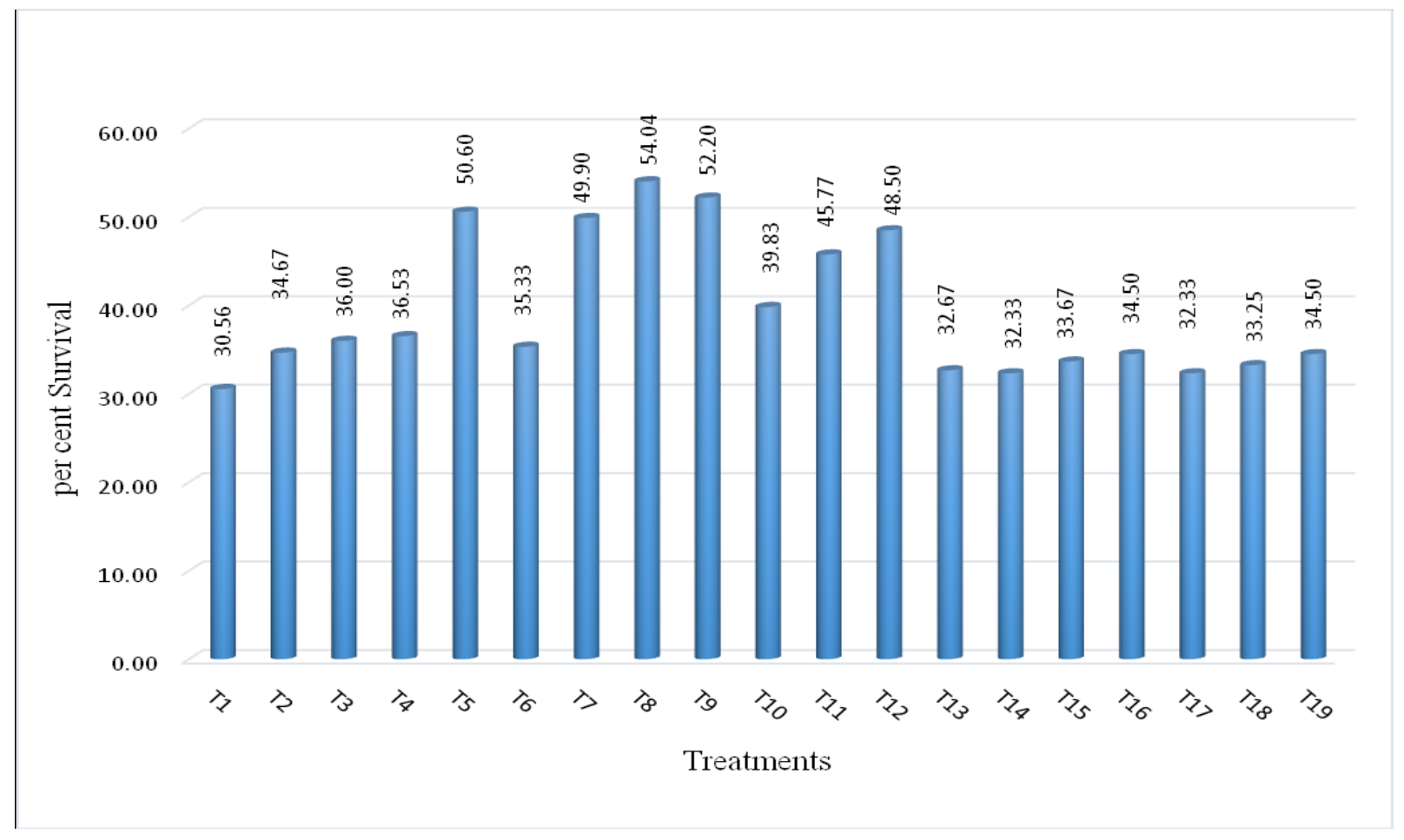


Table.1 Effect of growth hormones and PGPRs on various root parameters in Bush pepper cuttings

\begin{tabular}{|c|c|c|c|}
\hline Treatments & $\begin{array}{l}\text { Percentage of } \\
\text { cuttings rooted } \\
(\%)\end{array}$ & $\begin{array}{l}\text { Fresh } \\
\text { weight of } \\
\text { root }(\mathrm{g})\end{array}$ & $\begin{array}{l}\text { Dry weight } \\
\text { of root }(\mathrm{g})\end{array}$ \\
\hline$T_{1}$ - Control & 38.90 & 0.59 & 0.14 \\
\hline $\mathrm{T}_{2}-$ Pseudomonasfluorescens $5 \mathrm{ml}$ & 45.33 & 0.77 & 0.32 \\
\hline $\mathrm{T}_{3}-$ Pseudomonas fluorescens $10 \mathrm{ml}$ & 47.50 & 0.76 & 0.33 \\
\hline $\mathrm{T}_{4}-$ Azospirillumlipoferum $5 \mathrm{ml}$ & 47.68 & 0.78 & 0.34 \\
\hline $\mathrm{T}_{5}-$ Azospirillumlipoferum $10 \mathrm{ml}$ & 61.84 & 0.89 & 0.48 \\
\hline$T_{6}-$ Keradix & 44.17 & 0.77 & 0.32 \\
\hline $\mathrm{T}_{7}=$ IBA 750 ppm & 61.20 & 0.85 & 0.29 \\
\hline$T_{8}-$ IBA 1000 ppm & 65.30 & 1.10 & 0.53 \\
\hline $\mathrm{T}_{9}-\mathrm{IBA} 1250 \mathrm{ppm}$ & 63.52 & 1.00 & 0.50 \\
\hline$T_{10}-$ NAA 200 ppm & 51.12 & 0.71 & 0.26 \\
\hline 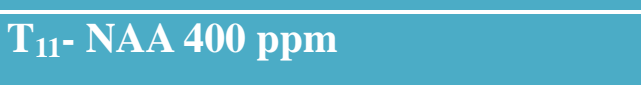 & 56.95 & 0.70 & 0.24 \\
\hline$T_{12}-$ NAA 600 ppm & 59.80 & 0.68 & 0.25 \\
\hline $\mathrm{T}_{13}-2,4 \mathrm{D} 100 \mathrm{ppm}$ & 44.17 & 0.66 & 0.21 \\
\hline$T_{14}-2,4 \mathrm{D} 200 \mathrm{ppm}$ & 41.18 & 0.65 & 0.20 \\
\hline$T_{15}-2,4$ D 300 ppm & 40.95 & 0.64 & 0.19 \\
\hline $\mathrm{T}_{16}$ - Cow dung slurry $1: 1$ & 44.79 & 0.64 & 0.19 \\
\hline $\mathrm{T}_{17}-$ Cow dung slurry $1: 2$ & 43.40 & 0.61 & 0.18 \\
\hline $\begin{array}{l}T_{18}-\text { Tender coconut water @ } \mathbf{5 0 \%} \\
\text { dilution }\end{array}$ & 42.50 & 0.63 & 0.19 \\
\hline $\begin{array}{l}T_{19}-\text { Tender coconut water } \\
\text { concentrated }\end{array}$ & 45.34 & 0.60 & 0.18 \\
\hline S. Em. \pm & 1.39 & 0.04 & 0.01 \\
\hline CD@ 5\% & 4.17 & 0.12 & 0.03 \\
\hline
\end{tabular}


Table.2 Economics of nursery production of bush pepper

\begin{tabular}{|c|c|c|c|c|c|}
\hline Treatments & $\begin{array}{c}\text { Total cost } \\
\text { (₹) }\end{array}$ & $\begin{array}{c}\text { Total } \\
\text { number of } \\
\text { saleable } \\
\text { plants }\end{array}$ & $\begin{array}{c}\text { Gross } \\
\text { income } \\
(₹)\end{array}$ & $\begin{array}{c}\text { Net } \\
\text { income } \\
\text { (₹) }\end{array}$ & $\begin{array}{l}\text { B : C } \\
\text { Ratio }\end{array}$ \\
\hline$T_{1}-$ Control & 4500 & 305.60 & 9168 & 4668 & 2.04 \\
\hline $\mathrm{T}_{2}-$ Pseudomonasfluorescens $5 \mathrm{ml}$ & 4740 & 346.70 & 10401 & 5661 & 2.19 \\
\hline $\mathrm{T}_{3}-$ Pseudomonas fluorescens $10 \mathrm{ml}$ & 4980 & 360.00 & 10800 & 5820 & 2.17 \\
\hline $\mathrm{T}_{4}-$ Azospirillumlipoferum $5 \mathrm{ml}$ & 4740 & 365.30 & 10959 & 6219 & 2.31 \\
\hline $\mathrm{T}_{5}$ - Azospirillumlipoferum $10 \mathrm{ml}$ & 4980 & 506.00 & 15180 & 10200 & 3.05 \\
\hline $\mathrm{T}_{6}$ - Keradix & 4640 & 353.30 & 10599 & 5959 & 2.28 \\
\hline $\mathrm{T}_{7}-\mathrm{IBA} 750 \mathrm{ppm}$ & 4665 & 499.00 & 14970 & 10305 & 3.21 \\
\hline $\mathrm{T}_{8}-\mathrm{IBA} 1000 \mathrm{ppm}$ & 4720 & 540.40 & 16212 & 11492 & 3.43 \\
\hline $\mathrm{T}_{9}-\mathrm{IBA} 1250 \mathrm{ppm}$ & 4775 & 522.00 & 15660 & 10885 & 3.28 \\
\hline $\mathrm{T}_{10}$ - NAA 200 ppm & 4501 & 398.30 & 11949 & 7447 & 2.65 \\
\hline $\mathrm{T}_{11}$ - NAA 400 ppm & 4503 & 457.70 & 13731 & 9227 & 3.05 \\
\hline $\mathrm{T}_{12}$ - NAA 600 ppm & 4505 & 485.00 & 14550 & 10044 & 3.23 \\
\hline $\mathrm{T}_{13}-2,4 \mathrm{D} 100 \mathrm{ppm}$ & 4501 & 326.70 & 9801 & 5299 & 2.18 \\
\hline $\mathrm{T}_{14}-2,4 \mathrm{D} 200 \mathrm{ppm}$ & 4502 & 323.00 & 9699 & 5196 & 2.15 \\
\hline $\mathrm{T}_{15}-2,4 \mathrm{D} 300 \mathrm{ppm}$ & 4503 & 336.00 & 10101 & 5597 & 2.24 \\
\hline$T_{16}-$ Cow dung slurry $1: 1$ & 4505 & 345.00 & 10350 & 5845 & 2.30 \\
\hline $\mathrm{T}_{17}$ - Cow dung slurry $1: 2$ & 4502 & 323.00 & 9699 & 5196 & 2.15 \\
\hline $\mathrm{T}_{18}$-Tender Coconut water @ 50\% dilution & 4560 & 332.00 & 9975 & 5415 & 2.19 \\
\hline $\mathrm{T}_{19}$ - Tender Coconut water concentrated & 4620 & 345.00 & 10350 & 5730 & 2.24 \\
\hline
\end{tabular}

The economics of nursery production of bush pepper was worked out (Table 2). The treatment $\mathrm{T}_{3}$ (Pseudomonas fluorescens $10 \mathrm{ml}$ ) and $\mathrm{T}_{4}$ (Azospirillum lipoferum 10ml) incurred in higher cost of production (₹ 4980.00 and ₹ 4980.00respectively).

The treatment $\mathrm{T}_{8}$ (IBA $1000 \mathrm{ppm}$ ) recorded maximum gross income (₹ 16212.00 per 1000 cuttings) and net income (₹ 11492.00 per cuttings). The treatment $\mathrm{T}_{8}$ (IBA $1000 \mathrm{ppm}$ ) also recorded maximum $\mathrm{B}$ : $\mathrm{C}$ ratio of $1: 3.43$ followed by $\mathrm{T}_{9}$ - IBA $1250 \mathrm{ppm}$ (1:3.28). IBA $1000 \mathrm{ppm}$, IBA $1250 \mathrm{ppm}$ have been found to induce better root system in plagiotropic black pepper cuttings.

The basis for this might be enhancement of hydrolysis of nutrient reserves (mainly starch) by auxin treatments. According to Nanda, (1975) enhanced hydrolysis activity in the presence of exogenously applied hormones was responsible for the increased rooting in auxin treated cuttings. These results were in 
the conformity with the findings of Nirupadi (2017).

The results of the study confirmed that, application of IBA at $1000 \mathrm{ppm}$ proved to be beneficial in promoting better root growth and survivability of plagiotropic cuttings in black pepper.

\section{References}

Bandi, B., Parmar, B. R., Parmar, S. B. and Parmar, K. 2012. Effect of auxins on shoot and root growth in an endangered medicinal plant guggal [Commiphora wightii (Arnott.) Bhand.]. J. Hortl. Sci., 7(2):211-213.

Bhagya, H.P. and Sreeramu, B.S. 2013. Effect of growth regulators on vegetative propagation of Vitex negundo L., Asian J. Hort., 8(1): 209-212.

Camellia, N. A., Thohirah, L. A., Abdullah, N. A. P. and Khidir, O. M. 2009. Improvement on rooting quality of Jatropha curcas using Indol Butyric Acid (IBA). Res. J. Agri. Bio. Sci., 5(4): 338-343.

Das, B., Tantry, F. A. and Srivastava, K. K. 2006. Rooting response of olive stem cuttings under zero energy environment. Indian J. Hort., 63(2): 209-212.

Devasahayam, S., Anandaraj, M., Thankamani, C. K., Saji, K. V. and Jayashree, E. 2010. Black pepper In: Parthasarathy, V. A. and Rajeev, P. A. (Eds.) Major spices- production and processing. Indian Institute of Spice Research, Calicut, pp. 15-61.

Kaur, S., Cheema, S. S., Chhabra, B. R. and Talwar, K. K. 2002. Chemical induction of physiological changes during adventitious root formation and bud break in grapevine cuttings. Plant Growth Regul., 37: 63-68.

Murthy, G., Umesha, K. Smitha, G. R. and Krishnamanohar, R. 2010. Effect of growth regulators and bio-inoculants on rooting and growth of vanilla stem cuttings. Indian J. Hort. 67(1), March 2010: 90-93

Nanda, K. K. 1975. Physiology of adventitious root formation. Indian J. Pl. physiol., 18: 80-89.

Nirupadi. 2017. Effect of growth regulators on rooting of stem cuttings in Barbados cherry (Malphighia glabra L.). M. Sc. Hort. Thesis, Univ. Agri. Horti. Sci., Shivamogga, Karnataka (India). p 56.

Polat, A. A. and Caliskan, O. 2009. Effect of IBA on rooting cutting in various pomegranate genotypes. Acta Hort., 818: 187-192.

Sujatha, V. S., Nair, A. S. and Nybe, E. V. 2004.Performance of different types of planting material in the rooting and establishment of bush pepper. Indian J. Hort.; 61: 287-288.

Susaj, E., Susaj, L. and Kallco, I. 2012. Effects of different NAA and IBA concentration on rooting of vegetative cuttings of two rose cultivars. Res. J. Agri. Sci., 44(3): 121-127.

\section{How to cite this article:}

Sannidhi, H.S., H.R. Bhoomika, B.M. Priyanka, M.S. Nandish, G. Raviraja Shetty and Ganapathi, M. 2018. Influence of Plant Growth Promoting Substances on Rooting of Bush Pepper Cuttings. Int.J.Curr.Microbiol.App.Sci. 7(09): 1685-1690. doi: https://doi.org/10.20546/ijcmas.2018.709.204 